\title{
Prevalence and Perpetrators of Domestic Violence against Adolescents in Rivers State.
}

\author{
Stella Okey-Orji \\ Department of Human Kinetics and Health Education, \\ University of Port Harcourt. \\ Emmanuel U. Asogwa (Ph. D.) \\ Department of Human Kinetics and Health Education, \\ University of Port Harcourt, \\ Rivers State, Nigeria.
}

\begin{abstract}
The study investigated prevalence and perpetrators of domestic violence against adolescents in Rivers State. Cross sectional and co-relational designs were used for the study. Three research questions guided the study and four hypotheses were postulated and tested. The population for the study was 93,076 adolescents in Rivers State Senior Secondary Schools. A sample size of one thousand five hundred and twelve (1512) respondents was selected using multistage sampling procedures. The instrument for data collection was validated self-structured/adapted 59-item questionnaire titled domestic violence prevalence and perpetrators questionnaire (DVPPQ). The data generated were subjected to statistical analysis using mean and standard deviation to answer the research questions, while Z-test and ANOVA were used to test the hypotheses at 0.05 alpha levels. The findings of the study revealed that domestic violence against adolescents was prevalent in Rivers State with grand mean of 2.63. Guardians, siblings and parents were the major perpetrators of physical, verbal, economic and emotional abuses, while relatives, friends and neighbors were the perpetrators of sexual abuse against adolescents. The findings also revealed that age, parents' /guardians' educational and occupational status had no significant influence on the perpetration of domestic against adolescents but gender did. Based on the findings, the study recommended among others that integrated approaches be adopted to curb the menace of domestic violence in the society, particularly in Rivers State.
\end{abstract}

Keywords: Domestic violence, Adolescent, Perpetrator

\section{INTRODUCTION}

Domestic violence (DV) has been recognized as a global public health problem affecting various individuals including adolescents with its attendant negative effects. According to Alvarez Davidson, Fleming and Glass (2016), the phenomenon has attracted careful attention from numerous national and international establishments, yet its prevalence is increasing on a daily basis and has continued to be a persistent social problem cutting across religious, racial and cultural borders. World Health Organization [WHO] (2017) revealed that domestic violence against adolescents progresses to domestic violence in adult relationship hence the need to break the cycle.

DV prevalence varies globally and among different demographic groups. For instance, WHO(2017) reported that domestic violence against adolescents is on the rise as 1.6 million adolescents have been anguished from one form of ill treatment within the family settings to another. Femi-Ajao, (2018) observed that Sub Saharan Africa remains the most affected as confirmed by previous research studies which revealed up to fifty-one per cent prevalence. In Nigeria, the prevalence of DV is on the increase, as according to Musawa (2016) and Nigeria 
Demographic and Health Survey (2008) reported that about twenty to thirty per cent of adolescents experienced DV from the age fifteen to nineteen. In Africa, it is observed that females are more abused violently than males. Abayomi, Kolawde and Olabode (2013) found out that homicides associated with DV were reported to be six times higher for females than males. WHO (2016) also reported that 84million female adolescents have been abused emotionally, physically or sexually by someone within the family cycle.

Domestic violence has been described by studies as an array of abusive or threatening behavior with the purpose of exerting power and maintaining control over the victim, and occurs commonly within the family setting. DV is sometimes interchanged with family violence (Ahmed, Chowdhury \& Laskar, 2017; Bamiwuye \& Odemegwu, 2014). It includes any attempts by any person in intimate relationship to manipulate, dominate, or use his or her position to exercise control over a person, using fear, threat, intimidation and other forms of abusive behaviours and actions (Segal, Smith, Robinson,\& Segal, 2018). In the context of this study, DV is any abusive behavior or action taken against adolescent by an close partner or anyone in the family cycle, which is harmful to wellbeing of such individual, and perpetrator can described as one who exhibits any form of abusive behavior towards another or others. In relation to DV, a perpetrator is a person within the family setting who causes physical, emotional, verbal, economic or sexual abuse to another person (adolescent).

Domestic violence against adolescents can be perpetrated in various forms. According to studies, the forms include physical abuse such as flogging, kicking, beating, pushing, slapping, hair pulling, knocking (Derries, Knight, Petzold, Merrill, Williams, \& Abrahams, 2018; UNICEF, 2017), sexual abuse, such as unpermitted touches, teasing, forceful intercourse or rape(WHO, 2016; Sinha, Mallik, Sanyal, Dasgupta, Pal, \& Murherjee, 2012), verbal abuse expressed as blaming, name-calling, accusations, ranting, and statements that are capable of causing loss of elf-esteem and self-worth (WHO,2017), emotional or psychological abuse (Essein, 2017; Akmatov, 2011), economic abuse such as exploiting an adolescents through street hawking (Nduka \& Duru, 2014), dating violence among adolescents involved in intimate relationship (Onanubi, Olumide,\& Owoaje, 2017), female genital mutilation (Ahmed, Chowdhury, \& Laskar, 2017), and early marriage (WHO, 2017). According to studies, the effects of DV are overwhelming on the victim's physical, mental, social, emotional and reproductive, including exposure to life-threatening diseases like Hepatitis, HIV/AIDS, and other unwholesome conditions and practices such as unwanted pregnancies, unsafe abortions among others

Adolescents constitute an appreciable percentage of the general population, and are by nature seen as 'seeds' for future generations. WHO Reports show that low- and middle-income countries, including Nigeria are home to more than ninety per cent $(90 \%)$ of the world's children and youths (WHO, 2017). These are the future adults with great potentials of becoming productive members of the society who can contribute meaningfully to the socioeconomic development of the society. Family is a micro system and agent of socialization, and a home for care and protection of this age group which should inculcate values, morals, skills and positive behaviors in them, and provide them with the basic necessities, care and protection that would enable them progress into successful adulthood. Unfortunately, this is not the case in developing countries where children and adolescents are treated as objects or possessions without souls and rights as human beings, perhaps, due to socio-cultural and religious factors.

Most adolescents live at home with their parents and other family members, and may be subjected to all forms of familial abuse or violence. Reports of prevalence of DV and abuse in developing countries revealing that the highest prevalence of DV against the young people is in 
Africa (Akmatov, 2011), with other such reports and observations, ignited the curiosity and desire of the researchers to investigate the prevalence and perpetrators of DV against adolescents in Rivers State, in order to proffer solutions to this menace of grievous social and health consequences. River State is a mixed of traditional and modern society, rich in crude deposits, a hub of oil and gas exploration activities, with a large population of adolescents of both aborigines and non- indigenes.

\section{Purpose of the Study}

The study intended to:

1. find out the prevalence of domestic violence against adolescents in Rivers State

2. identify perpetrators of DV against adolescents in Rivers State

3. ascertain the prevalence of DV against adolescents based on age, sex, parents'/guardians' educational status and occupation

\section{Research Questions}

The following research questions guided the study:

1. What is the prevalence of DV against adolescents in Rivers State?

2. Who are the perpetrators of DV against adolescents in Rivers State?

3. What is the prevalence of DV against adolescents in Rivers State based on age, sex, parents/guardians' educational status and occupation?

\section{Hypotheses}

The following hypotheses were postulated and tested at 0.05 alpha levels:

1. There is no significant difference in the prevalence of DV against adolescents based on age.

2. There is no significant difference in the prevalence of DV against adolescents based on sex.

3. There is no significant difference in the prevalence of DV against adolescents based on the parent'/guardians' educational status

4. There is no significant difference in the prevalence of DV against adolescents based on parents/guardians' occupation

\section{METHODOLOGY}

The study adopted descriptive survey and correlation design. The population for the study consisted of 93,076 adolescents from all public secondary schools on Rivers State (Rivers State Senior Secondary School Board RSSSSB, 2019). A sample size of 1512 respondents was selected using multi-stage procedures. Validated self-structured and adapted questionnaire was used for data collection. Mean and Standard Deviation were used to answer the research questions, while Z-test and ANOVA were used to test the hypotheses at 0.05 alpha level 


\section{RESULTS AND ANALYSIS}

Research Question 1: What is the prevalence of domestic Violence among adolescents in Rivers State?

Table 1: The prevalence of physical violence against adolescents in Rivers State ( $N=1512)$

\begin{tabular}{clccccccc}
\hline S/N & $\begin{array}{l}\text { Prevalence of } \\
\text { Physical Abuse }\end{array}$ & $\begin{array}{c}\text { Always } \\
\text { (A) }\end{array}$ & $\begin{array}{c}\text { Sometimes } \\
\text { (S) }\end{array}$ & $\begin{array}{c}\text { Rarely } \\
\text { (R) }\end{array}$ & $\begin{array}{c}\text { Never } \\
\text { (N) }\end{array}$ & $\begin{array}{c}\text { Mean } \\
\mathbf{x}\end{array}$ & SD & Decision \\
\hline 1 & Hitting & 987 & 447 & 45 & 33 & 3.58 & .66 & \\
2 & slapping & 609 & 633 & 70 & 200 & 3.09 & .99 & \\
3 & flogging & 781 & 367 & 299 & 65 & 3.23 & .91 & \\
4 & Kicking & 89 & 199 & 655 & 569 & 1.87 & .85 & \\
5 & Pushing & 883 & 231 & 197 & 300 & 3.19 & 1.10 & \\
6 & Dragging & 779 & 651 & 3 & 79 & 3.41 & .75 & \\
7 & Suffocation & 211 & 59 & 369 & 873 & 1.74 & 1.05 & \\
8 & Putting pepper in the & 107 & 59 & 256 & 1090 & 2.18 & .54 & \\
& eyes & & & & & & \\
9 & Bites & 211 & 99 & 296 & 906 & 1.75 & 1.08 & \\
10 & Burns & 188 & 190 & 344 & 790 & 1.85 & 1.06 & \\
11 & Pull of hair & 90 & 258 & 283 & 881 & 1.71 & .95 & Sometimes abused. \\
& Grand mean and & & & & & & & \\
& standard deviation. & & & & & $\mathbf{2 . 4 7}$ & $\mathbf{0 . 9 0}$ & \\
\hline
\end{tabular}

Legend: 0-1 (never), 1.1-2 (rarely), 2.1-3(sometimes) and 3.1-4 (always)

Data in table 1 showed that the overall mean for physical abuse was 2.47 which indicates that adolescents in Rivers State were sometimes physically abused.

Table 2: The prevalence of verbal abuse among adolescents in Rivers State.( $\mathrm{N}=1512)$

\begin{tabular}{|c|c|c|c|c|c|c|c|c|}
\hline $\mathrm{S} / \mathrm{N}$ & Verbal Abuse & Always & Sometimes & Rarely & Never & Mean & Std & Decision \\
\hline$\overline{11}$ & Shouting & 9912 & 4456 & 23 & 10121 & 3.42 & 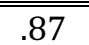 & \\
\hline 2 & $\begin{array}{l}\text { Making shameful remarks } \\
\text { about me }\end{array}$ & 886 & 334 & 132 & 160 & 3.29 & 1.01 & \\
\hline 3 & $\begin{array}{l}\text { Accusations/blaming } \\
\text { Grand mean and Standard } \\
\text { Deviation }\end{array}$ & 997 & 112 & 123 & 280 & $\begin{array}{l}3.21 \\
3.31\end{array}$ & $\begin{array}{l}1.19 \\
1.02\end{array}$ & Always \\
\hline
\end{tabular}

Legend: 0-1 (never), 1.1-2 (rarely), 2.1-3 (sometimes) and 3.1-4(always)

Data in table 2 had a grand mean of 3.31which showed that there was always verbal abuse of adolescents in Rivers State. 
Table 3: Prevalence of emotional/psychological violence among adolescents in Rivers State ( $\mathrm{N}=1512)$

\begin{tabular}{|c|c|c|c|c|c|c|c|c|}
\hline $\mathrm{S} / \mathrm{N}$ & $\begin{array}{l}\text { Prevalence of } \\
\text { Emotional/Psychological } \\
\text { Abuse. }\end{array}$ & Always & Sometimes & Rarely & Never & Mean & Std & Decision \\
\hline $\mathrm{i}$ & Locking me up in a room & 865 & 212 & 200 & 235 & 3.13 & 1.14 & \\
\hline ii & Intimidation & 744 & 244 & 274 & 250 & 2.98 & 1.16 & \\
\hline iii & Hatred/malice & 655 & 434 & 300 & 123 & 3.07 & .98 & \\
\hline iv & $\begin{array}{l}\text { Preventing me from visiting } \\
\text { my friends. }\end{array}$ & 223 & 29 & 583 & 677 & 1.87 & 1.02 & \\
\hline $\mathrm{v}$ & $\begin{array}{l}\text { Preventing my friends from } \\
\text { visiting me }\end{array}$ & 156 & 211 & 354 & 791 & 1.82 & 1.02 & \\
\hline vi & Threaten to disown me & 861 & 122 & 279 & 250 & 3.05 & 1.19 & \\
\hline vii & $\begin{array}{l}\text { Refusal to provide my basic } \\
\text { needs }\end{array}$ & 917 & 199 & 76 & 320 & 3.13 & 1.22 & \\
\hline viii & $\begin{array}{l}\text { Making jest of me } \\
\text { Grand mean and Standard } \\
\text { deviation }\end{array}$ & 779 & 402 & 312 & 19 & 2.79 & 1.07 & $\begin{array}{c}\text { Sometimes } \\
\text { abused }\end{array}$ \\
\hline
\end{tabular}

Legend: 0-1 (never), 1.1-2 (rarely), 2.1-3 (sometimes) and 3.1-4(always)

Table 4.6.2 showed that making jest of respondents was the most common emotional abuse (3.28) followed by not providing their needs (3.13), locking respondents up (3.13), hatred /malice (3.07), threaten to disown respondents (3.05) and intimidation (2.98). The emotional abuse, respondents never experienced were preventing them from seeing their friends (1.87) and preventing their friends from seeing them (1.82). Summation of the item Means gave a grand mean of 2.8, implying that emotional abuse was sometimes prevalent among respondents.

Table 4: Prevalence of economic abuse among adolescents in Rivers State ( $N=1512)$

\begin{tabular}{|c|c|c|c|c|c|c|c|c|}
\hline S/N & Economic Abuse & A & $S$ & $\mathbf{R}$ & $\mathbf{N}$ & $\mathbf{x}$ & SD & Decision \\
\hline$\overline{\mathrm{i}}$ & Hawking in the street & 688 & 412 & 111 & 301 & 2.88 & 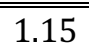 & \\
\hline ii & $\begin{array}{l}\text { Selling in the shop during } \\
\text { school hours }\end{array}$ & 711 & 256 & 211 & 334 & 2.98 & 1.22 & \\
\hline iii & $\begin{array}{l}\text { Going to farm during school } \\
\text { hours }\end{array}$ & 209 & 312 & 367 & 627 & 2.07 & 1.08 & \\
\hline \multirow[t]{2}{*}{ iv } & $\begin{array}{l}\text { Refusal to pay my school } \\
\text { fees }\end{array}$ & 790 & 412 & 10 & 300 & 3.12 & 1.14 & \\
\hline & $\begin{array}{l}\text { Grand Mean and Standard } \\
\text { Deviation }\end{array}$ & & & & & 2.76 & 1.15 & Sometimes \\
\hline
\end{tabular}

Legend: 0-1 (never), 1.1-2 (rarely), 2.1-3 (sometimes) and 3.1-4(always)

Table 4 revealed that refusal to pay respondents' school fees had the highest mean response; 790 (3.12) followed by selling in the shopx during school hours 711 (2.89), hawking in the street 688 (2.98) while going to farm during school hours attracted the lowest mean response (2.07). The grand mean for economic abuse was 2.76 which indicated that the students were sometimes economically abused. 
Table 5. Prevalence of sexual abuse among adolescents in Rivers State ( $\mathrm{N}=1512)$.

\begin{tabular}{|c|c|c|c|c|c|c|c|c|}
\hline $\mathbf{S} / \mathbf{N}$ & Sexual Abuse & Always & Sometimes & Rarely & Never & Mean & Std & Decision \\
\hline 1 & $\begin{array}{l}\text { Unpermitted } \\
\text { touches/hugs/caressing }\end{array}$ & 211 & 222 & 198 & 881 & 1.84 & 1.11 & \\
\hline 2 & Teasing & 219 & 200 & 278 & 815 & 1.88 & 1.11 & \\
\hline 3 & Kissing & 321 & 187 & 160 & 844 & 1.99 & 1.24 & \\
\hline 4 & $\begin{array}{l}\text { Attempted rape through the } \\
\text { offering of money }\end{array}$ & 266 & 167 & 339 & 740 & 1.97 & 1.14 & \\
\hline 5 & $\begin{array}{l}\text { Forcing me to touch his/her } \\
\text { private part. } \\
\text { Grand Mean and Standard }\end{array}$ & 176 & 190 & 423 & 723 & 1.88 & 1.03 & \\
\hline & Deviation & & & & & 1.84 & .12 & Rarely \\
\hline
\end{tabular}

Legend: 0-1 (never), 1.1-2 (rarely), 2.1-3 (sometimes) and 3.1-4(always)

Table 5 revealed that majority of the respondents never experienced sexual abuse like unpermitted touches/ hugs/caressing 881 (1.84),kissing 844 (1.99), teasing 815 (1.88), attempted rape $740(1.97)$ and 723 respondents (1.88) never experienced being forced to touch someone's genitals (private part). However, some respondents accepted having experienced sexual abuse as shown in the table above even though the grand mean (1.84) reflected that they rarely experience sexual abuse.

In summary, verbal abuse had the highest mean score (3.31) followed by emotional/psychological abuse (2.79), economic abuse (2.76), physical abuse (2.47) and sexual abuse (1.84) with a grand mean of 2.63 indicating that domestic violence was prevalent among adolescents in Rivers State.

\section{Research Question 2: Who are the perpetrators of domestic violence against adolescents in Rivers State?}

Table 6: The perpetrators of physical abuse among adolescents in Rivers State $(\mathrm{N}=1512)$

\begin{tabular}{clccccccc}
\hline \hline S/N & Perpetrators of Physical Abuse & $\mathbf{A}$ & $\mathbf{S}$ & $\mathbf{R}$ & $\mathbf{N}$ & $\mathbf{X}$ & SD & Decision \\
\hline \hline 1 & My parents & 698 & 398 & 212 & 204 & 3.05 & 1.07 & \\
2 & My guardian & 900 & 333 & 244 & 35 & 3.38 & .84 & \\
3 & Siblings (brother or sister) & 766 & 438 & 8 & 300 & 3.10 & 1.14 & \\
4 & Other relatives & 897 & 296 & 87 & 292 & 3.22 & 1.18 & \\
5 & My intimate friend & 889 & 239 & 212 & 172 & 3.22 & 1.07 & \\
6 & My neighbor & 123 & 917 & 155 & 317 & 2.95 & 1.19 & \multirow{2}{*}{ Always } \\
& Grand Mean and Standard & & & & & $\mathbf{3 . 1 5}$ & $\mathbf{1 . 0 8}$ & \\
& Deviation & & & & & &
\end{tabular}

Legend: 0-1 (never), 1.1-2 (rarely), 2.1-3 (sometimes) and 3.1-4(always)

Table 4.7.1 showed that adolescents in Rivers State were always physically abused by guardians who had the highest positive responses for physical abuse 900 (3.38) followed by other relatives 897 (3.22) and intimate friends 887 (3.22), siblings 766 (3.10) and parents 698 (3.05). Those who sometimes render physical abuse to the students were their neighbors 917 (2.95). 
Table 7: The perpetrators of verbal abuse among adolescents in Rivers State ( $N=1512)$.

\begin{tabular}{|c|c|c|c|c|c|c|c|}
\hline $\mathrm{S} / \mathrm{N}$ & $\begin{array}{l}\text { Perpetrators of Verbal } \\
\text { abuse }\end{array}$ & A & $\mathbf{S}$ & $\mathbf{R}$ & $\mathbf{N}$ & $\mathbf{x}$ & SD \\
\hline 1 & My parents & 966 & 229 & 287 & 30 & 3.41 & .99 \\
\hline 2 & My guardian & 859 & 412 & 122 & 119 & 3.19 & 1.03 \\
\hline 3 & Siblings & 877 & 345 & 102 & 188 & 3.26 & 1.04 \\
\hline 4 & Other relatives & 769 & 512 & 98 & 133 & 3.07 & .92 \\
\hline 5 & My intimate friend & 945 & 267 & 159 & 141 & 3.33 & .86 \\
\hline \multirow[t]{2}{*}{6} & My neighbor & 856 & 345 & 11 & 300 & 3.16 & 1.16 \\
\hline & $\begin{array}{l}\text { Grand Mean and Standard } \\
\text { Deviation }\end{array}$ & & & & & 3.27 & 1.00 \\
\hline
\end{tabular}

Table 7 revealed that parents had the highest positive responses 966 (3.41) followed by intimate friends 945 (3.33), siblings 877 (3.26), guardians 859 (3.19), neighbors 856 (3.16) and lastly other relatives $769(3,07)$. The table showed that the perpetrators that verbally abuse respondents were their parents, friends, siblings, guardians;neighbors and other relatives and friends with parents as the highest perpetrators.

Table 8: The perpetrators of psychological/emotional abuse among adolescents in Rivers State $(\mathrm{N}=1512)$.

\begin{tabular}{|c|c|c|c|c|c|c|c|c|}
\hline & $\begin{array}{l}\text { Perpetrators of emotional } \\
\text { abuse }\end{array}$ & A & $\mathbf{S}$ & $\mathbf{R}$ & $\mathbf{N}$ & $\mathbf{x}$ & SD & Decision \\
\hline 1 & My parents & 866 & 313 & 109 & 224 & 3.21 & 1.00 & \\
\hline 2 & My guardian & 658 & 356 & 213 & 285 & 2.92 & 1.15 & \\
\hline 3 & Siblings (brother or sister) & 699 & 413 & 235 & 165 & 3.09 & 1.02 & \\
\hline 4 & Other relatives & 967 & 512 & 11 & 22 & 3.60 & .58 & \\
\hline 5 & My intimate friend & 786 & 414 & 111 & 174 & 3.20 & 1.09 & \\
\hline & $\begin{array}{l}\text { Grand Mean and Standard } \\
\text { Deviation }\end{array}$ & & & & & 3.20 & 0.97 & Always \\
\hline
\end{tabular}

Table 9 revealed that other relatives had the highest positive responses for emotional abuse 967 (3.60) followed by parents 886 (3.21) friend 786 (3.20), siblings (3.09), guardian had the lowest positive responses 658 (2.96). The grand mean (3.20) is an indication that the respondents experienced emotional abuse in the home setting with relatives, parents, intimate friends, siblings and guardians as perpetrators.

Table 9: The perpetrators of sexual abuse among adolescents in Rivers State ( $N=1512)$

\begin{tabular}{|c|c|c|c|c|c|c|c|}
\hline$S / N$ & $\begin{array}{l}\text { Perpetrators of sexual } \\
\text { abuse }\end{array}$ & A & 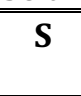 & $\bar{~} \mathbf{R}$ & $\mathbf{N}$ & $\mathbf{X}$ & SD \\
\hline 1 & My parents & 12 & 2 & 19 & 1479 & 1.04 & .29 \\
\hline 2 & My guardian & 7 & 5 & 23 & 1477 & 1.04 & .26 \\
\hline 3 & Siblings & 1 & 7 & 3 & 1501 & 1.01 & .16 \\
\hline 4 & Other relatives & 983 & 299 & 218 & 12 & 3.49 & .77 \\
\hline 5 & My intimate friend & 866 & 430 & 78 & 138 & 3.34 & .94 \\
\hline \multirow[t]{2}{*}{6} & My neighbor & 798 & 511 & 66 & 137 & 3.31 & .91 \\
\hline & $\begin{array}{l}\text { Grand Mean and Standard } \\
\text { Deviation }\end{array}$ & & & & & 2.21 & 0.56 \\
\hline
\end{tabular}

Table 9 showed that relatives had the highest positive responses 983 (3.49) as those who sexually abuse respondents followed by their intimate friends 866 (3.34) and neighbors 798 (3.31). Parents, guardians and siblings had the lowest positive responses 12 (1.04), 7 (1.04) and 8 (1.01) respectively indicating that they never abuse respondents sexually. 
Table 10: The perpetrators of economic abuse among adolescents in Rivers State $(\mathrm{N}=1512)$.

\begin{tabular}{|c|c|c|c|c|c|c|c|}
\hline S/N & $\begin{array}{l}\text { Perpetrators of Economic } \\
\text { abuse }\end{array}$ & A & $S$ & $\mathbf{R}$ & $\mathbf{N}$ & $\mathbf{x}$ & SD \\
\hline 1 & My parents & 856 & 433 & 47 & 200 & 3.35 & 1.02 \\
\hline 2 & My guardian & 587 & 432 & 89 & 404 & 2.79 & 1.21 \\
\hline 3 & Siblings & 832 & 389 & 208 & 59 & 3.25 & .86 \\
\hline 4 & Other relatives & 67 & 58 & 349 & 1038 & 1.44 & .77 \\
\hline 5 & My intimate friend. & 103 & 155 & 321 & 933 & 1.62 & .92 \\
\hline \multirow[t]{2}{*}{6} & My neighbor & 178 & 218 & 376 & 740 & 1.79 & 1.78 \\
\hline & $\begin{array}{l}\text { Grand Mean and Standard } \\
\text { Deviation }\end{array}$ & & & & & 2.37 & 1.07 \\
\hline
\end{tabular}

Table 10 revealed that parents had the highest positive responses 856 (3.35) as perpetrators of economic abuse against adolescents in Rivers State. Others are siblings 832 (3.25), guardians 587 (2.79). On the other hand, the table showed that relatives, intimate friends and neighbors had the lowest positive responses for economic abuse 67 (1.44), 103 (1.62), 178 (2.37) respectively with grand mean of 2.37 .

\section{Research Question 3: What is the prevalence of domestic violence among adolescents in Rivers State based on socio-demographic variables of age, sex, parents'/guardians' educational and occupational status?}

Table 11: Mean and standard deviation on prevalence of domestic violence among adolescents based on age, sex, parents educational status and parents occupational status

\begin{tabular}{|c|c|c|c|c|c|c|c|c|c|c|c|c|c|c|c|c|c|c|c|}
\hline \multirow[t]{2}{*}{$S / N$} & \multirow{2}{*}{$\begin{array}{c}\text { Prevalence of Domestic } \\
\text { Violence among } \\
\text { Adolescents in Rivers } \\
\text { State } \\
\end{array}$} & \multicolumn{2}{|c|}{ Age } & \multicolumn{2}{|c|}{ Sex } & \multicolumn{4}{|c|}{ Educational Status of Mother } & \multicolumn{4}{|c|}{ Educational Status of Father } & \multicolumn{3}{|c|}{$\begin{array}{c}\text { Mothers Occupational } \\
\text { Status }\end{array}$} & \multicolumn{2}{|c|}{$\begin{array}{c}\text { Fathers } \\
\text { Occupational } \\
\text { Status }\end{array}$} & \multirow[b]{2}{*}{$\begin{array}{r}\mathbf{G E}= \\
\mathbf{x}\end{array}$} \\
\hline & & $\begin{array}{c}14- \\
\text { 16yers } \\
\text { mean }\end{array}$ & $\begin{array}{l}15- \\
19 y e a r s\end{array}$ & $\mathrm{M}=\mathrm{x}$ & $F=x$ & $\begin{array}{l}\mathrm{NF} \\
=\mathrm{x}\end{array}$ & $P=x$ & $S=x$ & $T=x$ & $\mathrm{NF}=\mathrm{x}$ & $P=x$ & $S=x$ & $T=x$ & $\begin{array}{l}\mathrm{JL}= \\
\mathrm{x}\end{array}$ & $\begin{array}{c}\mathrm{SE}= \\
\mathrm{x}\end{array}$ & $\begin{array}{c}\mathrm{GE}= \\
\mathrm{x}\end{array}$ & $\mathrm{JL}=\mathrm{x}$ & $\mathrm{SE}=\mathrm{x}$ & \\
\hline 1 & Sexual Abuse & 2.42 & 2.49 & 2.53 & 2.62 & 2.33 & 2.39 & 2.36 & 2.35 & 2.33 & 2.45 & 2.45 & 2.42 & 2.42 & 2.34 & 2.44 & 2.33 & 2.36 & 2.41 \\
\hline 2 & Emotional Abuse & 3.18 & 2.91 & 3.1 & 3.00 & 2.91 & 3.10 & 3.11 & 3.07 & 3.03 & 2.98 & 2.99 & 3.05 & 3.07 & 3.07 & 3.00 & 3.04 & 3.01 & 3.01 \\
\hline 3 & Verbal Abuse & 3.37 & 3.02 & 3.48 & 3.11 & 3.71 & 3.59 & 3.59 & 3.59 & 3.08 & 3.47 & 3.28 & 3.21 & 3.13 & 3.43 & 3.19 & 3.06 & 3.20 & 3.05 \\
\hline 4 & Economic Abuse & 2.40 & 2.33 & 2.434 & 2.35 & 2.33 & 2.26 & 2.39 & 2.43 & 2.36 & 2.30 & 2.25 & 2.31 & 2.43 & 2.33 & 2.43 & 2.39 & 2.131 & 2.38 \\
\hline 5 & Physical Abuse & 3.00 & 3.10 & 3.27 & 3.16 & 3.25 & 3.37 & 3.47 & 3.53 & 3.37 & 3.38 & 3.42 & 3.49 & 3.30 & 3.39 & 3.30 & 3.16 & 3.36 & 3.16 \\
\hline
\end{tabular}

Table 11 revealed that grand means of the sexual abuse, emotional abuse, verbal abuse, economic abuse and physical abuse, verbal abuse, economic abuse and physical abuse were above the criterion mean of 2.50, indicating that adolescents in Rivers State experienced domestic violence irrespective of their age, sex, parents' / guardians educational level and occupational status.

\section{TEST OF HYPOTHESES}

There is no significant difference in the prevalence of domestic violence among adolescents in Rivers State with regards to socio-demographic variables of age, sex, parents/guardians educational status and parents/guardians' occupation.

Z-test was used to test the variables of age and sex while One Way Analysis of Variance was used to test the variables of parents educational status and parents/guardians' occupation.

Table 12: z-test on the prevalence of domestic violence based on age

\begin{tabular}{c|cccccccc}
\hline Age & $\boldsymbol{N}$ & $\boldsymbol{m e a n}$ & $\boldsymbol{S D}$ & $\boldsymbol{d} \boldsymbol{f}$ & $\boldsymbol{z}$-cal & $\boldsymbol{p}$-val. & Alpha level & Decision \\
\hline 14-16years & 1169 & 3.40 & 0.08 & & & & & Not \\
15-19years & 343 & 3.39 & 0.15 & 1510 & 1.25 & 0.58 & 0.05 & significant \\
\hline
\end{tabular}


Table 12 showed that students between the ages of 14- 16 years had mean and standard deviation scores of 3.40 and 0.08 while those within the ages of 15 years to 19years had mean and standard deviation scores of 3.39 and 0.15 respectively. With a degree of freedom of 1510 , the calculated z-test value of 1.25 is not significant because the probability value of 0.58 is greater than the alpha level of 0.05 . Therefore, there age did not significantly influence the prevalence of domestic violence among adolescents in Rivers State.

Table 13: z-test on the prevalence of domestic violence based on sex

\begin{tabular}{|c|c|c|c|c|c|c|c|c|}
\hline Sex & N & Mean & Std & df & z-cal & p-val. & Alpha level & Decision \\
\hline Male students & 823 & 3.79 & 0.29 & & & & & Significant \\
$\begin{array}{c}\text { Female } \\
\text { students }\end{array}$ & 689 & 3.73 & 0.28 & 1510 & 6.00 & 0.02 & 0.05 & \\
\hline
\end{tabular}

Table 13 showed that male students have mean and standard deviation scores of 3.79 and 0.29 while female students have mean and standard deviation scores of 3.73 and 0.28 respectively. With a degree of freedom of 1510, the calculated z-test value of 6.000 is significant because the probability value of 0.02 is greater than the alpha level of 0.05 .

Therefore, there sex significantly influenced the prevalence of domestic violence among adolescents in Rivers State.

Table 14: ANOVA on the prevalence of domestic violence based on mothers' education

\begin{tabular}{|l|c|c|c|c|c|c|c|}
\hline & Sum of Squares & df & $\begin{array}{c}\text { Mean } \\
\text { Square }\end{array}$ & F & $\begin{array}{c}\text { P- } \\
\text { value }\end{array}$ & $\begin{array}{c}\text { Alpha } \\
\text { level }\end{array}$ & Decision \\
\hline Between Groups & 9.870 & 3 & 3.290 & .351 & .789 & 0.05 & $\begin{array}{c}\text { Hypothesis is } \\
\text { accepted }\end{array}$ \\
Within Groups & 14150.130 & 1508 & 9.383 & & & & \\
Total & 14160.000 & 1511 & & & & \\
\hline
\end{tabular}

Table 14 showed that the sum of squares for between groups and within groups are 9.870 and 14150.130 while the mean squares for between and within groups are 3.290 and 9.383 respectively. The degrees of freedom are 3 and 1508 with $F$ ratio of 0.351 which is not significant because the probability value of 0.789 is greater than the alpha level of 0.05 . Therefore, mothers' education did not significantly influence prevalence of domestic violence in secondary schools in Rivers State.

Table 15: ANOVA on the prevalence of domestic violence based on fathers' education

\begin{tabular}{|l|c|c|c|c|c|c|c|}
\hline & Sum of Squares & Df & $\begin{array}{c}\text { Mean } \\
\text { Square }\end{array}$ & F & P-value & Alpha level & Decision \\
\hline Between Groups & 8.940 & 3 & 2.980 & .318 & .813 & 0.05 & $\begin{array}{c}\text { Hypothesis is } \\
\text { accepted }\end{array}$ \\
Within Groups & 14151.060 & 1508 & 9.384 & & & & \\
Total & 14160.000 & 1511 & & & & \\
\hline
\end{tabular}

Table 15 showed that the sum of squares for between groups and within groups are 8.940 and 14151.060 while the mean squares for between and within groups are 2.980 and 9.384 respectively. The degrees of freedom are 3 and 1508 with $F$ ratio of 0.318 which is not significant because the probability value of 0.813 is greater than the alpha level of 0.05 . Therefore, fathers' education did not significantly influence prevalence of domestic violence in secondary schools in Rivers State. 
Table 16: ANOVA on the prevalence of domestic violence based on mothers' occupation

\begin{tabular}{|l|c|c|c|c|c|c|c|}
\hline & Sum of Squares & df & $\begin{array}{c}\text { Mean } \\
\text { Square }\end{array}$ & $\mathbf{F}$ & P-val. & Alpha level & Decision \\
\hline Between Groups & 2.450 & 3 & 0.817 & .131 & .878 & 0.05 & $\begin{array}{c}\text { Hypothesis is } \\
\text { accepted }\end{array}$ \\
$\begin{array}{l}\text { Within Groups } \\
\text { Total }\end{array}$ & 14157.550 & 1508 & 9.388 & & & & \\
\hline
\end{tabular}

Table 16 showed that the sum of squares for between groups and within groups are 2.450 and 14157.550 while the mean squares for between and within groups are 0.817 and 9.388 respectively. The degrees of freedom are 3 and 1508 with $F$ ratio of 0.131 which is not significant because the probability value of 0.878 is greater than the alpha level of 0.05 . Therefore, mothers' occupation did not significantly influence prevalence of domestic violence in secondary schools in Rivers State.

Table 17: ANOVA on the prevalence of domestic violence based on fathers' occupation

\begin{tabular}{|l|c|c|c|c|c|c|c|}
\hline & Sum of Squares & Df & $\begin{array}{c}\text { Mean } \\
\text { Square }\end{array}$ & F & P-val. & Alpha level & Decision \\
\hline Between Groups & 5.890 & 3 & 1.963 & .197 & .731 & 0.05 & Hypothesis \\
Within Groups & 15054.010 & 1508 & 9.983 & & & & is accepted \\
Total & 15059.900 & 1511 & & & & & \\
\hline
\end{tabular}

Table 17 showed that the sum of squares for between groups and within groups are 5.890 and 15054.010 while the mean squares for between and within groups are 1.963 and 9.983 respectively. The degrees of freedom are 3 and 1508 with $F$ ratio of 0.197 which is not significant because the probability value of 0.731 is greater than the alpha level of 0.05 . Therefore, fathers' occupation did not significantly influence prevalence of domestic violence in secondary schools in Rivers State.

\section{DISCUSSION OF FINDINGS}

\section{Prevalence of Domestic Violence against Adolescents}

The findings of the study in tables 1-5 showed that domestic violence was prevalent among adolescents in Rivers State with a grand mean of 2.63 which included physical abuse (2.47) verbal abuse (3.31), emotional abuse (2.79), economic abuse (2.76) and sexual abuse(1.84) However, this study revealed that verbal abuse had the highest mean score (3.31) among other forms of domestic violence experienced by adolescents. This is sad because, this type of abuse may not be recognized as an abuse yet it has devastating effect on the adolescents who may choose to endure and withdraw to themselves thereby suffering emotional trauma and low self-esteem. The nature of physical abuse experienced by adolescents as found in this study included hitting, slapping, dragging and pulling of hair among others. This finding is not surprising because similar studies conducted by UNICEF (2017) showed that adolescents are exposed to these various forms of domestic violence. These study's findings corroborated the report of Agala, Adebiyi and Nkem(2018) which found prevalence of physical abuse to be $33.5 \%$ and sexual abuse (13\%), and reports of Meinick, Cluver and Loening-Voysey (2017) which revealed a lifetime prevalence of $68.9 \%$ for physical abuse and $32.3 \%$ monthly prevalence among adolescents in South Africa. The findings also agreed with that of Oluremi(2015) and Ebhohimen(2015) who posited that adolescents and women are exposed to various forms of domestic violence. This is a source of concern because adolescents are future adults whose potentials can be harnessed for the benefit of their families and society. Even though, the present showed a slight reduction in the prevalence of domestic violence 
against adolescents as compared to previous findings, it is still worrisome that domestic violence is still a threat to the well-being and health of the young people in the society.

The result showed that economic abuse was the second to the least form of domestic abuse experienced by adolescents with mean score of 2.37. This is not surprising because most respondents (51\%) lived in urban and semi-urban areas and 57\% of their parents/guardians had secondary/tertiary education. The findings also showed that adolescents in Rivers State also experienced emotional abuse (grand mean -3.20) with the commonest being the use of derogatory statements (3.28), refusal to provide basic needs(3.13), being locked up in the room(3.13) malice (3.07) and intimidation (2.98) while preventing friends from visiting them was rare (1.82). This may not be a surprise due to the fact that it is convenient for adolescents' to visit them under the supervision of their parents/guardians than being allowed to go out to socialize which may expose them to external influence. However, the result of this study is in line with that of Gordon (2019) which showed that, such abuses are dangerous because it is often not easily recognized as abuse, and therefore it can go on for prolonged periods, causing severe damage to victim's self-esteem and self-worth.

The study also found out as shown in table 5 that sexual abuse was the least common (mean score-1.84). This finding agreed with previous finding made by Eke, Agala, Adebiyi and Nkem (2018) which revealed a prevalence rate of $13 \%$ being the least compared to other forms of domestic violence. However, this finding disagreed with that of Manyike, Chinawa, Aniwada, Udechukwu, Otutola and Awoere(2015) which found out a prevalence rate of $40 \%$ for sexual abuse. This difference may be related to age difference of respondents. In their study, majority of their respondents (70\%) fell within the ages of 15-19years while in this study, majority of the respondents $(77 \%)$ fell within the ages of $14-16$ years. Also, this study had more male adolescents (54\%) than females (46\%) hence the finding is not surprising as confirmed by reports made by WHO (2016) and UNICEF (2017) that more females within the ages of 1519years experienced sexual violence than their male counterparts.

\section{Perpetrators of Domestic Violence against Adolescents}

The findings of this study in tables 6-10 showed that the perpetrators of DV against adolescents in Rivers State varied based on forms of abuse. For instance parents/guardians, and relatives were the highest perpetrators of physical abuse (Mean scores- 3.38, 3.22, 3.10). This finding is similar to that of Devries et al (2018) and WHO (2018) who reported that the most common perpetrators of physical violence are household members. This finding is not surprising because these are people who have authority and influence over adolescents hence they sometimes resort to physical abuse as a way of exercising discipline and control over them.

The study also found out that the highest perpetrators of emotional/psychological abuse against adolescents in Rivers State were parents/guardians, sibling, relatives and intimate friends (Mean scores 3.21, 2.91, 3.09, 3.60 and 3.20 respectively). This finding is not strange as it agreed with findings made by WHO (2017) and Gordon (2019) who found out that most adolescents were emotionally abused by people close to them and using this form of abuse as a way of making their victims conform to their wishes. Surprisingly, this study showed that the highest perpetrators of emotional abuse against adolescents were their relatives contrary to the findings of Meink, Cluver, Boyes and Loening-Voysey (2019) noted that the highest perpetrators of emotional abuse were parents/guardians.

The study revealed that perpetrators of sexual abuse against adolescents were relatives (3.49) intimate friends (3.34) and neighbors (3.31). This finding is in line with that of UNICEF (2017) 
and Sinha(2012) who affirmed that adolescents were sexually abused by people related to them.

The test of null hypothesis on the significant differences between socio-demographic variables and prevalence of domestic violence against adolescents in Rivers State showed that the variables of age, sex, parents/guardians' educational/occupational status had no significant difference on prevalence of domestic violence against adolescents except sex. Although, this finding seems surprising but it is not out of place as previous researchers like NDHS (2013), Bamiwuye and Odimegwu(2014) and Cools and Kotsadam(2017) found that domestic violence victimization and perpetration occur irrespective of age, sex and socio-economic status. The finding of this study also corroborates with(CDC, 2018; Trinh, Oh, Choi, To, \& Van Do, 2016)which showed that, domestic violence cuts across all households irrespective educational level, occupation, large family size, access to formal education.

\section{CONCLUSION}

Domestic violence is prevalent among adolescents in Rivers State with physical, verbal, economic and emotional abuse being the highest and sexual abuse being the least form of domestic abuse experienced, respectively.

The major perpetrators of domestic violence were parents/guardians, relatives, intimate friends and siblings. Adolescents were abused physically, emotionally and verbally irrespective of their age and sex as well as their parents/guardians' educational status, and parents/guardians' occupation in Rivers State.

\section{RECOMMENDATIONS}

The following recommendations were made based on the findings of the study:

1. Community-based sensitization programmes should be aggressively carried out to target socio-cultural norms that favour violence against any persons, including the young people

2. Government and policy-making bodies should ensure the implementation of Child Right Act, and stringent measures against perpetrators of domestic violence in any forms, especially the young people, who the future adults

3. Comprehensive life skills education programmes should be incorporated in the primary and secondary school curriculum as a stand-alone subject to ensure early inculcation and practice of these skills before they face the larger society. Adolescents should be encouraged to speak out and report perpetrators of any form of DV against them, as non-reporting and underreporting helps to encourage cycle of DV perpetration

4. Attitudes that condone or tolerate violence against adolescents and victimization should be discouraged by individuals, communities, institutions and laws/policies in all parts of the country. Parents/guardians and other family members should appropriate behaviours for adolescents to emulate, hence they need re-orientation and education on the effects of DV.

5. There is the need for integrated approach where all stakeholders including religious organizations join hands in creating a safe environment for young people in the home setting which will gradually diffuse to the larger society. 


\section{References}

Abayomi, A. A., Kolawole, \& Olabode, T. (2013). Domestic Violence and Death: Women as Endangered Gender in Nigeria. American Journal of Sociological Research, 3(3), 53-60.

Ahmed, M., Chowdhury, I. U. A., \& Laskar, S. S. (2017). Domestic Violence in Relation to Women Empowerment and Women Household Headship: A Case in Nigeria. Nile Journal of Business and Economics, 3(7), 15-27. https://doi.org/10.20321/nilejbe.v3i7.118

Akmatov, M. K. (2011). Child abuse in 28 developing and transitional countries--results from the Multiple Indicator Cluster Surveys. International Journal of Epidemiology, 40(1), 219-227. https://doi.org/10.1093/ije/dyq168

Alvarez, C. P., Davidson, P. M., Fleming, C., \& Glass, N. E. (2016). Elements of Effective Interventions for Addressing Intimate Partner Violence in Latina Women: A Systematic Review. PLOS ONE, 11(8), e0160518. https://doi.org/10.1371/journal.pone.0160518

Bamiwuye, S. O., \& Odimegwu, C. (2014). Spousal violence in sub-Saharan Africa: does household poverty-wealth matter? Reproductive Health, 11(1), 45. https://doi.org/10.1186/1742-4755-11-45

CDC. (2018, October 3). Prevent Domestic Violence. Retrieved February 28, 2019, from Centers for Disease Control and Prevention website: https://www.cdc.gov/features/intimatepartnerviolence/index.html

Cools, S., \& Kotsadam, A. (2017). Resources and Intimate Partner Violence in Sub-Saharan Africa. World Development, 95, 211-230. https://doi.org/10.1016/j.worlddev.2017.02.027

Devries, K., Knight, L., Petzold, M., Merrill, K. G., Maxwell, L., Williams, A., ... Abrahams, N. (2018). Who perpetrates violence against children? A systematic analysis of age-specific and sex-specific data. BMJ Paediatrics Open, 2(1), e000180. https://doi.org/10.1136/bmjpo-2017-000180

Ebhohimen, S. (2015, June 20). Prevalence Of Domestic Violence In Nigeria. Retrieved October 9, 2018, from Nigerian Observer website: http://nigerianobservernews.com/2015/06/prevalence-of-domestic-violence-innigeria/

Essien, C. (2017, August 21). Solutions To Domestic Violence In Nigeria -By Barr. Christiana Essien. Retrieved March 8, 2019, from Opinion Nigeria website: http://www.opinionnigeria.com/solutions-to-domestic-violencein-nigeria-by-barr-christiana-

Femi-Ajao, O. (2018). Intimate partner violence and abuse against Nigerian women resident in England, UK: a cross- sectional qualitative study. BMC Women's Health, 18(1), 123. https://doi.org/10.1186/s12905-018-0610-4

García-Moreno, C., Pallitto, C., Devries, K., Stöckl, H., Watts, C., \& Abrahams, N. (2013). Global and regional estimates of violence against women: prevalence and health effects of intimate partner violence and non-partner sexual violence. Geneva, Switzerland: World Health Organization.

Gordon, S. (2019). How to Recognize Verbal Abuse and Bullying. Retrieved November 26, 2019, from Verywell Mind website: https://www.verywellmind.com/how-to-recognize-verbal-abuse-bullying-4154087

Musawa, H. (2016, May 14). Surging Domestic Violence Rate Against Women In Nigeria. Retrieved October 15, 2018, from The Nation Nigeria website: http://thenationonlineng.net/surging-domestic-violence-rate-womennigeria/

Nduka, I., \& Duru, C. O. (2014). The menace of street hawking in Aba metropolis, South-East Nigeria. Journal of Medicine and Medical Sciences, 5(6), 133-140.

Nigeria Demographic and Health Survey. (2008). Nigeria Demographic and Health Survey. 20.

Onanubi, K. A., Olumide, A. O., \& Owoaje, E. T. (2017). Prevalence and Predictors of Intimate Partner Violence Among Female Youth in an Urban Low-Income Neighborhood in Ibadan, South-West Nigeria. SAGE Open, 7(2), 2158244017715673. https://doi.org/10.1177/2158244017715673

Rivers State Senior Secondary School Board; Planning, Research and Statistics Department (RSSSSB). (2019). LGA Breakdown of Students Enrollment, 2018/2019 Session. Port Harcourt.

Segal, J., Smith, M., Robinson, L., \& Segal, R. (2018). Stress in the work place: Managing job and work stress. Retrieved Form Https://Www. Helpguide. Org/Articles/Stress/Stress-in-Theworkplace. Htm. USA.

Sinha, A., Mallik, S., Sanyal, D., Dasgupta, S., Pal, D., \& Mukherjee, A. (2012). Domestic violence among ever married women of reproductive age group in a slum area of Kolkata. Indian Journal of Public Health, 56(1), 31.

https://doi.org/10.4103/0019-557X.96955 
Trinh, O. T. H., Oh, J., Choi, S., To, K. G., \& Van Do, D. (2016). Changes and socioeconomic factors associated with attitudes towards domestic violence among Vietnamese women aged 15-49: findings from the Multiple Indicator Cluster Surveys, 2006-2011. Global Health Action, 9. https://doi.org/10.3402/gha.v9.29577

UNICEF. (2017). A familiar face: violence in the lives of children and adolescents. Retrieved from https://data.unicef.org/resources/a-familiar-face

World Health Organization. (2016). INSPIRE: seven strategies for ending violence against children. Retrieved from http://www.who.int/violence_injury_prevention/violence/inspire/en

World Health Organization. (2017, November 29). Violence against women. Retrieved February 28, 2019, from https://www.who.int/news-room/fact-sheets/detail/violence-against-women 